\title{
"PELATIHAN PEMBUATAN KARTU DENGAN ORIGAMI MENGAMBIL TEMA HEWAN LANGKA INDONESIA" (RPTRA Dharma Suci- Jakarta)
}

\author{
Yana Erlyana $^{1 \text { )* }}$ dan Henny Hidajat ${ }^{2)}$ \\ ${ }^{1)}$ Desain Komunikasi Visual/Fakultas Teknologi dan Desain, Universitas Bunda Mulia \\ ${ }^{2)}$ Desain Komunikasi Visual/Fakultas Teknologi dan Desain, Universitas Bunda Mulia
}

Diterima 16 Juli 2019 / Disetujui 28 Agustus 2019

\begin{abstract}
Environmental education has a very important role in overcoming current environmental problems. The development of environmental awareness is increasingly important to continue to be socialized to all elements of society who have a responsibility in maintaining and preserving the environment for sustainability that is relevant to nature. Early childhood must begin to have an awareness of the importance of environmental aspects in maintaining life now and in the future because environmental education is the responsibility of the entire community, including government and educational institutions. This community service activity combines the provision of material on the importance of preserving the environment, especially Indonesian rare animals and development of children's fine motor skill by using paper folding activities or commonly called origami. This study using collaborative and participatory action research methods (PAR). At the community service this time, the target of the participants was children aged 6-8 years in the North Jakarta Dharma Suci RPTRA environment. The results of the training from this activity showed that children tend to be enthusiastic in participating in giving the material given. Children tend to be interested in learning more about rare animals in Indonesia. And it can be seen that the children's fine motor skills, namely in folding paper (origami), seem to be better in several processes in the process of folding paper.
\end{abstract}

Keywords: Preserving, Environment, Animal, Origami, PAR

\begin{abstract}
ABSTRAK
Pendidikan lingkungan memiliki peranan yang sangat penting dalam mengatasi permasalahan lingkungan yang timbul saat ini. Pengembangan kesadaran lingkungan hidup semakin penting untuk terus disosialisasikan kepada semua elemen masyarakat yang memiliki tanggung jawab dalam mempertahankan dan melestarikan lingkungan demi keberlanjutan yang relevan dengan alam. Anak usia dini harus mulai memiliki kesadaran akan pentingnya aspek lingkungan dalam mempertahankan kehidupan saat ini dan di masa depan karena pendidikan lingkungan hidup merupakan tanggung jawab seluruh masyarakat, termasuk pemerintah dan lembaga pendidikan. Kegiatan pengabdian kepada masyarakat ini memadukan dari pemberian materi tentang pentingnya melestarikan lingkungan hidup terutama hewan-hewan langka Indonesia dan pengembangan motorik halus anak usia dini mengunakan kegiatan melipat kertas atau yang biasa disebut origami. Penelitian ini mengunakan metode penelitian tindakan kolaboratif dan partisipatori (participatory action research/ PAR). Pada kegiatan pengabdian kepada masyarakat kali ini, sasaran peserta adalah anak usia 6-8 tahun dilingkungan RPTRA Dharma Suci Jakarta Utara. Hasil pelatihan dari kegiatan ini anak-anak terlihat cenderung antusias dalam mengikuti pemberian materi yang diberikan. Anak-anak cenderung mulai tertarik untuk mempelajari lebih lanjut mengenai hewan-hewan langka di Indonesia. Serta terlihat bahwa kemampuan motorik halus anak-anak yaitu dalam melipat kertas (origami) terlihat menjadi lebih baik dalam beberapa proses tahapan penglipatan kertas.
\end{abstract}

Kata Kunci: Pelestarian, Lingkungan, Hewan, Origami, PAR

\footnotetext{
*Korespondensi Penulis:

E-mail: yerlyana@bundamulia.ac.id
} 


\section{PENDAHULUAN}

Indonesia merupakan negara pusat keanekaragaman hayati laut dunia sehingga memiliki yang kaya dengan hasil laut, sehingga banyak masyarakat yang memanfaatkan sumber daya laut untuk memenuhi kebutuhan hidup maupun dalam pemenuhan kebutuhan ekonomi. Ancaman terbesar datang dari masyarakat yang seharusnya melestarikan dan menjaga potensi lautan Indonesia. Kerusakan pada laut disebabkan karena perilaku manusia yang membabi buta mengeksploitasi laut tanpa memperhatikan aturan selain itu ancaman lokal juga datang dari pembangunan pesisir, pembangunan tambak dengan menghancurkan hutan mangrove dan juga penangkapan ikan yang berlebihan. Dari data penelitian Lembaga Ilmu Pengetahuan Indonesia (LIPI) secara berkesinambungan terungkap, kerusakan terumbu karang di Indonesia yang merupakan salah satu komponen penting ekosistem laut kini telah mencapai 70 persen. Kerusakan ekosistem laut ini sudah terjadi hampir di seluruh wilayah pesisir, karena kesadaran masyarakat tentang lingkungan masih rendah. Masyarakat harus menyadari dan wajib melindungi keberadaan ekosistem laut sebagai penopang hidup mereka.

Seperti yang dikutip dari detik.com 23/11/2016, sekolah-sekolah di Manado misalnya menurut ketua LSM Manengkel sudah membiasakan anak-anak mempelajari ekosistem laut. Menurutnya, ada 3 jenjang pendidikan di sekolah tersebut. Jenjang pertama yakni tempat di mana anak-anak diajari materi hingga ia memiliki pemahaman tentang lingkungan. Mulai dari materi soal ekosistem, pengolahan sampah, jurnalistik, sampai mitigasi bencana. Setelah itu ada jenjang transformer. Dalam jenjang ini, diharapkan rasa cinta anak terhadap lingkungan sudah tumbuh dan pemikiran mereka sudah berubah.

Tribun Bali 26/7/2018 Banyuwangi memulai kampanye pada anak-anak untuk membiasakan diri cinta pada ekosistem. Banyuwangi Sea Turtle Foundation (BSTF) bersama, Bank Central Asia (BCA), mengempanyekan kelestarian ekosistem laut, utamanya keberadaan penyu, di sekolah- sekolah. Menurut Executive Vice President Corporate Social Responsibility (CSR) BCA Inge Setiawati, "Anak-anak memiliki daya ingat yang tinggi akan sesuatu. Kegiatan ini agar mereka terbiasa dan selalu ingat untuk menjaga ekosistem laut, utamanya dalam hal ini adalah penyu.

Pendidikan lingkungan memiliki peranan yang sangat penting dalam mengatasi permasalahan lingkungan yang timbul saat ini. Pengembangan kesadaran lingkungan hidup semakin penting untuk terus disosialisasikan kepada semua elemen masyarakat yang memiliki tanggung jawab dalam mempertahankan dan melestarikan lingkungan demi keberlanjutan yang relevan dengan alam. Anak usia dini harus mulai memiliki kesadaran akan pentingnya aspek lingkungan dalam mempertahankan kehidupan saat ini dan di masa depan karena pendidikan lingkungan hidup merupakan tanggung jawab seluruh masyarakat, termasuk pemerintah dan lembaga pendidikan.

Berdasarkan Sutrisno dalam Djoehaeni (2014) mengungkapkan bahwa Kepedulian terhadap lingkungan dapat ditumbuh kembangkan pada diri anak sejak usia dini. Untuk itu cara yang paling mendatangkan hasil yang relatif cepat dan memuaskan adalah dengan secara sadar mendidik anak untuk mencintai lingkungan.

Widodo dalam Jumilah (2014: 18) berpendapat bahwa motorik merupakan perkembangan pengendalian gerakan tubuh melalui kegiatan yang terkoordinir antara susunan saraf otot, otak, dan spinal cord. Perkembangan keterampilan motorik terbagi menjadi dua yaitu keterampilan motorik halus dan keterampilan motorik kasar. Keterampilan motorik halus menurut Mahendra dalam Sumantri (2005: 143) keterampilan motorik halus (fine motor skill) merupakan keterampilan yang memerlukan kemampuan untuk mengontrol otot-otot kecil atau halus untuk mencapai pelaksanaan keterampilan yang berhasil. Pada masa golden age yang berkaitan dengan motorik halus anak sangat penting dikembangkan, hal ini didukung oleh Andang Ismail (2006: 84) yang mengatakan bahwa motorik halus adalah untuk melatih agar terampil dan cermat menggunakan jari- 
jemarinya dalam kehidupan sehari-hari. Motorik halus adalah gerakan yang menggunakan otot-otot halus atau sebagian anggota tubuh tertentu, yang dipengaruhi oleh kesempatan untuk belajar dan berlatih. Hurlock (2013: 150) menyatakan bahwa motorik halus adalah kemampuan seseorang anak melakukan kegiatan yang berkaitan dengan pengendalian gerak dan memusatkan perhatian semakin muda anak, semakin lama waktu yang dibutuhkan untuk berkonsentrasi pada kegiatan yang berkaitan dengan pekembangan motorik halus. Cara melatih motorik anak adalah dengan media sederhana yaitu melipat kertas atau disebut juga origami.

Kata origami berasal dari bahasa Jepang yakni dari kata oru yang berarti melipat dan kami berarti kertas. Ketika kedua kata digabungkan ada sedikit perubahan namun tidak mengubah artinya, yakni dari kata kami menjadi gamisehingga bukan orikami tetapi origami maksudnya adalah melipat kertas. Melipat kertas (origami) adalah suatu teknik berkarya seni/kerajinan tangan yang umumnya dibuat dari bahan kertas dengan tujuan untuk menghasilkan aneka bentuk mainan, hiasan, benda fungsional, alat peraga dan kreasi lain (Andayani, 2012: 37).

Selain untuk memperkenalkan anak terhadap hewan yang langka dan mulai punah, pada PKM (Pengabdian Kepada masyarakat) kali ini anak-anak juga belajar ketrampilan dengan membuat origami hewan langka tersebut kemudian dijadikan kartu ucapan.

\section{IDENTIFIKASI MASALAH}

Mengutip dari berbagai sumber, ketidakpedulian sebagian besar umat manusia pada kemampuan dan daya dukung bumi, berbagai perubahan melanda seluruh permukaan bumi. Pemanasan global dan perubahan iklim berdampak pada naiknya temperatur udara mencapai $1,5-4,5$ derajat celcius dan merubah permukaan bumi secara radikal sehingga mempengaruhi kesehatan dan keamanan manusia. Selain itu, juga terjadi perubahan musim dan musnahnya berbagi jenis flora dan fauna. Didukung data penelitian dari Lembaga Ilmu Pengetahuan Indonesia (LIPI) secara berkesinambungan terungkap, kerusakan terumbu karang di Indonesia yang merupakan salah satu komponen penting ekosistem laut kini telah mencapai 70 persen. Kerusakan ekosistem laut ini sudah terjadi hampir di seluruh wilayah pesisir, karena kesadaran masyarakat tentang lingkungan masih rendah. Masyarakat harus menyadari dan wajib melindungi keberadaan ekosistem laut sebagai penopang hidup mereka.

Untuk mengatasi permasalahan akibat dampak lingkungan, diperlukan keterlibatan segenap komponen masyarakat, tak terkecuali anak-anak. Anak merupakan generasi penerus yang mewariskan keberlangsungan bumi. Ketidakpedulian orang tua terhadap kelestarian lingkungan, bukan hanya mewariskan kondisi lingkungan yang buruk, namun juga menciptakan generasi penerus yang tak ramah lingkungan.

Berdasarkan Sutrisno dalam Djoehaeni (2014) mengungkapkan bahwa Kepedulian terhadap lingkungan dapat ditumbuh kembangkan pada diri anak sejak usia dini. Untuk itu cara yang paling mendatangkan hasil yang relatif cepat dan memuaskan adalah dengan secara sadar mendidik anak untuk mencintai lingkungan. Pendidikan yang diberikan haruslah mencangkup ke dalam semua aspek bidang pengembangan agar kemampuan anak dapat berkembang dengan maksimal dan menyeluruh. Salah satu bidang yang dikembangkan dalam pendidikan anak usia dini adalah perkembangan motorik.

Eksistensi perguruan tinggi ditentukan oleh kemampuannya memberi kontribusi pada masyarakat. Pengabdian masyarakat memiliki esensi yang sangat penting bagi aspek tata guna laksana dari pengembangan ilmu pengetahuan. Atas dasar nilai-nilai normatif tersebut di atas Program Studi Desain Komunikasi Visual Universitas Bunda Mulia Jakarta melakukan pelatihan untuk membantu anak-anak dalam melatih motorik halus anak dengan media origami. Pada kegiatan pengabdian kepada masyarakat kali ini, sasaran peserta adalah anak usia 6-8 tahun dilingkungan RPTRA Dharma Suci Jakarta Utara.

\section{TUJUAN DAN MANFAAT KEGIATAN}




\section{Adapun maksud dan tujuan diselenggarakan kegiatan PKM ini adalah untuk:}

a. Meningkatkan keinginan anak untuk ikut melestarikan lingkungan hidup terutama dalam hal ini hewan langka.

b. Meningkatkan kemampuan motorik halus anak pada usia dini.

c. Menambah dan mengembangkan kreatifitas anak dalam membuat origami.

\section{TINJAUAN PUSTAKA}

\section{Kajian Pendidikan Lingkungan Hidup}

Stapp (1979) menyatakan bahwa pendidikan lingkungan hidup adalah proses yang bertujuan untuk mengembangkan penduduk dunia yang sadar dan peduli terhadap lingkungan secara utuh serta permasalahan yang berhubungan dengan lingkungan, dan yang memiliki pengetahuan, sikap, motivasi, komitmen dan keterampilan untuk bekerja secara individu dan bersamasama terhadap solusi dari permasalahan saat ini dan pencegahan atas datangnya permasalahan yang baru.

Kinsella dalam djoehaeni (2014) menyatakan bahwa di masyarakat hari ini kita menjadi semakin khawatir tentang pemanasan global, perubahan iklim dan kesejahteraan planet ini dan habitat untuk generasi masa depan. Sebagai orangtua dan pengasuh, kita sering khawatir tentang masa depan anak-anak kita, dan banyak dari kita merasa kita bisa melakukan lebih dalam kehidupan sehari-hari kita untuk berkontribusi pada solusi bukan penyebab masalah lingkungan yang ditimbulkan. Di bagian lain dalam djoehaeni (2014) juga menyebutkan bahwa rumah kita dan masyarakat adalah tempat di mana kita membesarkan anak- anak kita, sehingga masuk akal untuk ingin menjaga rumah kita aman dan sehat bagi mereka untuk tumbuh dan belajar. Kita tahu bahwa anak-anak belajar dari hubungan dengan keluarga mereka, pengasuh dan lingkungan, sehingga, melalui apa yang kita lakukan dalam kehidupan kita sehari-hari, kita dapat mulai melibatkan anak- anak dalam belajar tentang merawat dunia di sekitar mereka.

\section{Keterampilan Motorik Halus}

Perkembangan motorik merupakan aktivitas yang familiar dengan kegiatan seharihari karena setiap hari digunakan oleh manusia untuk menjalani hidup. Menurut Hurlock (1978: 150) berpendapat bahwa perkembangan motorik berarti perkembangan pengendalian gerakan jasmaniah melalui kegiatan pusat syaraf, urat syaraf, dan otot yang terkendali. Corbin (Sumantri, 2005: 48) mengemukakan bahwa perkembangan motorik merupakan perubahan kemampuan gerak dari bayi sampai dewasa yang melibatkan berbagai aspek perilaku dan kemampuan gerak.

Pendapat di atas sesuai dengan pendapat Sujiono (2008: 1.3) yang menyatakan bahwa perkembangan motorik dapat disebut sebagai perkembangan dari unsur kematangan dan pengendalian gerak tubuh. Menurut Suyanto (2005: 51) menyatakan bahwa perkembangan motorik meliputi perkembangan badan, otot kasar (motorik kasar) dan otot halus (motorik halus).

Motorik merupakan pengendalian gerak tubuh melalui kegiatan yang terkoordinasi antara susunan syaraf, otot dan otak. Menurut Sujiono (2008: 1-15), "Motorik halus adalah gerakan tubuh yang melibatkan otot- otot kecil seperti otot jari tangan, pergelangan tangan dan lain-lain". Gerakan Motorik Halus terutama yang melibatkan otot tangan dan jari biasanya membutuhkan kecermatan tinggi, ketekunan dan koordinasi antara mata dan otot kecil. Semakin baik gerakan motorik halus membuat anak dapat berkreasi, seperti menggunting, menggambar, mewarnai, merobek, menulis, meronce, melipat, menjahit, meremas, menggenggam, menganyam dan sebagainya.

Jadi pengertian Kemampuan Motorik Halus anak adalah kesanggupan dalam suatu bidang tertentu yang berhubungan dengan gerakan yang melibatkan bagian-bagian tubuh tertentu saja dan dilakukan oleh otot-otot kecil seperti ketrampilan menggunakan jari-jari tangan dan gerakan pergelangan tangan, maka kemampuan motorik halus anak perlu diasah sedemikian rupa agar suatu saat nanti otot-otot jari tangan anak lebih kuat dan mampu untuk digunakan berbagai aktivitas yang berhubungan dengan motorik. 


\section{Definisi Origami}

Hira Karmachela (2006) berpendapat, bahwa kata origami berasal dari bahasa Jpeang yakni dari kata "Oru" yang berarti melipat dan "Kami" berarti kertas. Ketika kedua kata digabungkan ada sedikit perubahan namun tidak mengubah artinya, yakni dari kata "kami" menjadi "Gami" sehingga bukan "Orikami" tetapi menjadi "Origami" maksudnya adalah melipat kertas. Sedangkan Dr. Sumanto, melipat Origami adalah suatu teknik berkarya seni/ kerajinan tangan yang umumnya dibuat dari bahan kertas dengan tujuan untuk menghasilkan aneka bentuk mainan, hiasan, benda fungsional, alat peraga dan kreasi lainnya.

Origami atau yang lebih dikenal lagi dnegan istilah kertas lipat merupakan media (alat bantu) yang digunakan dalam pembelajaran kreativitas anak dengan segala bentuk dan saluran yang dugunakan para guru untuk menyalurkan pesan atau informasi. Dengan media kertas lipat yang bertujuan untuk menstimulus anak untuk mengembangkan kreativitasnya.

Melipat kertas adalah sesuatu yang sangat menyenangkan bagi anak karena dapat dibuat apa saja, mulai dari kegiatan melipat yang sederhana seperti bentuk segi tiga, segi empat, kemuian bentuk yang sulit. Gerak yang dilatih dari kegiatan melipat ini adalah bagaimana anak melipat dan menekan lipatanlipatan itu karena kegiatan ini akan memperkuat otot-otot telapak dan jari tangan anak.

Berkaitan dengan kegiatan melipat ini, Hira Karmachela berpendapat bahwa seni melipat kertas ini merupakan seni yang sangat cocok dengan anak karena Origami melatih keterampilan tangan anak, juga kerapian dalam berkreasi. Selain itu anak akan terbiasa untuk menciptakan hal baru atau inovasi. Melipat pada hakikatnya merupakan keterampilan tangan untuk meciptakan bentuk-bentuk tertentu tanpa menggunakan bahn perekat lem serta ketelitan ini membutuhkan keterampilan koordinasi tanga, ketelitian dan kerapian, di dalam kegiatan melipat jika disajikan dengan minat anak akan meberikan keasyikan dan kegembiraan serta kepuasan bagi anak. (Soemantri, 2005: 151)

\section{METODE PENELITIAN}

Kegiatan pengabdian kepada masyarakat ini memadukan dari pemberian materi tentang pentingnya melestarikan lingkungan hidup terutama hewan-hewan langka Indonesia dan mengunakan metode penelitian tindakan kolaboratif dan partisipatori (participatory action research/ PAR) yaitu kegiatan penelitian yang dilakukan dengan melibatkan masyarakat agar merasa ikut serta memiliki program kegiatan tersebut serta berniat ikut aktif memecahkan masalah berbasis masyarakat (Suharsimi Arikunto, 2006: 95). Masyarakat yang dimaksud dalam penelitian ini adalah anak usia 6-8 tahun dilingkungan RPTRA Dharma Suci Jakarta Utara.

Dalam teori PAR terdapat siklus yang dijadikan tolak ukur keberhasilan proses penelitian berbasis pemberdayaan masyarakat. Adapun siklus tersebut dikenal dengan istilah KUPAR (to Know, to Understand, to Plan, to Action dan to Reflection). To Know (untuk mengetahui) merupakan proses awal dalam pemberdayaan dengan mempertimbangkan pandangan subyektif peneliti terhadap kehidupan masyarakat yang diteliti, serta membangun kesepakatan sehingga peneliti diterima oleh masyarakat tersebut. To Understand (untuk memahami) dimaknai sebagai suatu proses dimana peneliti dan masyarakat yang diberdayakan mampu mengidentifikasi permasalahan yang ada dalam kehidupan mereka, kemudian dikolerasikan dengan aset-aset yang dimiliki masyarakat, sehingga dapat mewujudkan komitmen masyarakat dalam menyelesaikan permasalahan yang ada dalam kehidupan mereka. To Plan (untuk merencanakan) sebagai proses merencanakan aksi-aksi strategis dalam menyelesaikan persoalan yang muncul dalam masyarakat. Perencanaan ini mempertimbangkan keseimbangan antara human resources dan natural resources serta alur stakeholder yang menghimpun masyarakat tersebut. Tahap perencanaan ini harus dimaksimalkan dengan kesertaan penuh masyarakat atas penyelesaian masalahnya sendiri. Sehingga pemberdayaan tidak hanya diartikan sebagai perubahan sosial saja, namun juga media pendidikan masyarakat. To Action (melancarkan aksi) merupakan implementasi produk pemikiran masyarakat untuk membangun, mengelola, merubah, 
menajamkan aset-aset yang dimiliki masyarakat sehingga dapat difungsikan secara optimal dan proposional. To Reflection (refleksi) merupakan tahapan dimana peneliti dan masyarakat mengevaluasi dan memonitoring aksi pemberdayaan yang telah dilakukan sehingga pemberdayaan menjadi terarah dan terukur.

\section{HASIL DAN PEMBAHASAN}

Pemetaan awal yang dilakukan dalam penelitian ini adalah mempertimbangkan lingkungan sekitar dari universitas Bunda Mulia maka terpilih wilah RPTRA Dharma Suci yang berlokasi di Jakarta Utara. Dari peneltian sebelumnya dan pengamatan peneliti secara obyektif dan dikuatkan oleh seorang pengurus di wilayah RPTRA Dharma Suci tersebut diketahui bahwa permasalahan yang dihadapi oleh anak-anak sekitar adalah kurangnya pengembangan pengetahuan dalam pelestarian lingkungan. Serta perlu adanya peningkatan kemampuan motorik halus anak dan kreativitas.

Kemudian peneliti melakukan inkulturasi dan membangun kepercayaan yaitu dengan membuat kelompok-kelompok kecil dan bertanya secara personal kepada anak-anak (dibantu oleh asisten pembicara yang menjadi pendamping kelompok) untuk mengetahui sejauh mana anak-anak mengenal hewan langka Indonesia dan memahami sejauh mana kemampuan motorik halus anak terutama dalam melipat origami.

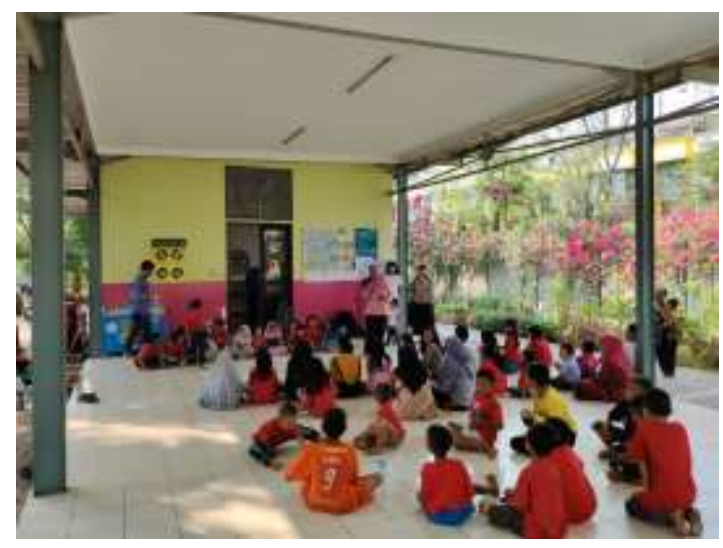

Gambar 1. Peserta Kegiatan (Anak-anak sekitar wilayah RPTRA Dharma Suci)

(Sumber: Penulis, 2019)

Kegiatan dilanjutkan dengan membagikan alat bantu berupa materi informasi (cara melipat secara tertulis), kertas origami, lem, kertas gambar, pensil warna. Kemudian instruktur memberikan penjelasan di depan dengan memaparkan pengetahuan umum mengenai hewan-hewan langka di Indonesia dan diikuti cara melipat kertas origami menjadi bentuk hewan langka, kemudian kertas origami yang telah terlipat ditempelkan pada sebuah kertas/ karton gambar, pada kertas gambar diberi tulisan berupa ucapan dan diakhiri dengan hiasan yang diinginkan oleh anak. Kartu ucapan dengan origami hewan langka Indonesia menjadi hasil dari proses kegiatan tersebut. Peserta mengikuti semua instruksi pengajar dan dibantu oleh pembimbing kelompok masing-masing melakukan pembuatan hewan langka mengunakan kertas origami. Adapun hewan yang diangkat dalam materi adalah Ikan Paus Biru (Balaenoptera musculus) dan Penyu Hijau (Chelonia mydas). Pemilihan kedua hewan ini didasarkan akan beberapa hal dan yang terutama tingkat kepunahan hewan tersebut yang cukup tinggi.

Ikan Paus Biru (Balaenoptera musculus) merupakan salah satu jenis satwa laut yang dilindungi di Indonesia. Bersama beberapa jenis ikan paus lainnya, Ikan Paus Biru hidup antara lain di perairan Lamalera dan Solor, Lembata, propinsi Nusa Tenggara Timur. Ikan yang dikenal oleh masyarakat setempat dengan sebutan kelaru ini memiliki semburan tepat di atas kepalanya. Jenis ikan paus ini panjang tubuhnya bisa mencapai 33 meter, dan bobot tubuhnya bisa mencapai 181 ton lebih. Menurut para ahli, ikan paus biru juga merupakan hewan yang memiliki suara paling nyaring di bumi dan mereka dapat saling berkomunikasi dengan kawanannya. Ikan ini dianggap oleh masyarakat Nusa Tenggara Timur sebagai nenek moyang mereka dan merupakan hewan yang bersifat sakral. Oleh karena itu penduduk beranggapan bahwa membunuh ikan paus biru adalah terlarang. Sekalipun ikan ini juga dapat ditemukan pada berbagai perairan lain di dunia, ikan ini telah banyak diburu dan dinyatakan hampir punah. Hingga akhirnya pada tahun 2008 lembaga konservasi internasional menggolongkan ikan paus biru sebagai hewan yang terancam punah dan menjadi hewan laut yang dilindungi. Hewan ini juga dilindungi oleh Pemerintah Indonesia. 


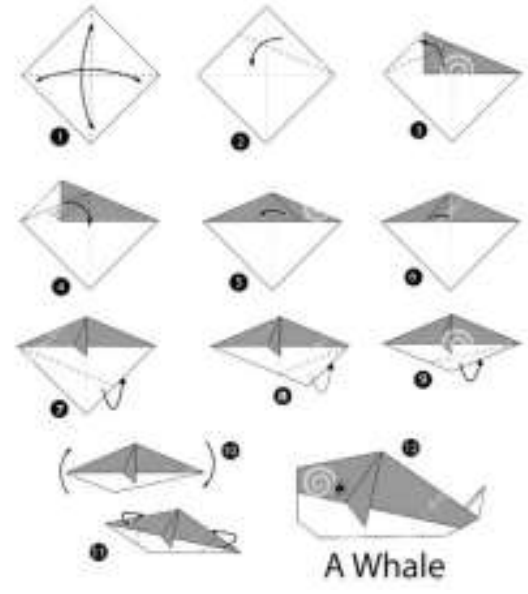

Gambar 2. Origami Paus Biru (Sumber: Internet, 2019)

Penyu Hijau (Chelonia mydas) termasuk hewan laut yang dilindungi di Indonesia. Penyu ini hidup di area perairan Kalimantan, terutama Kepulauan Derawan Kalimantan Timur, tempat mereka biasa bertelur. Penyu ini merupakan jenis yang paling sering ditemukan dan hidup di laut tropis. Ciri khasnya terdapat pada bentuk kepalanya yang kecil dan paruhnya yang tumpul. Nama penyu hijau berasal dari warna lemak yang ada di bawah sisiknya yang ternyata berwana hijau. Sedangkan warna tubuhnya sendiri bisa berwarna abu-abu, kehitaman atau kecoklatan. Lemaknya berwarna hijau karena penyu hijau merupakan herbivora laut yang makanan utamanya adalah rumput laut. Spesies dewasa penyu hijau banyak hidup di hamparan lautan berganggang dan akan bertelur setiap 3 hingga 4 tahun sekali. Sayangnya Penyu Hijau dan penyu-penyu laut lainnya yang tinggal di perairan Indonesia banyak dibunuh untuk dikonsumsi baik telur maupun dagingnya, dan cangkangnya digunakan untuk pajangan. Oleh karena itu pemerintah Indonesia menyatakan hewan ini sebagai hewan yang dilindungi.

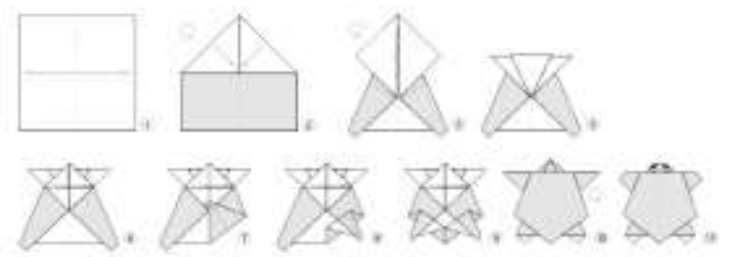

Gambar 3. Origami Penyu Hijau

(Sumber: Internet, 2019)

SIMPULAN
Hasil materi yang diberikan tentang bagaimana membuat kartu dengan origami mengambil tema hewan langka Indonesia kepada anak-anak usia 6-8 tahun dilingkungan RPTRA Dharma Suci Jakarta Utara:

1. Anak-anak cenderung antusias dalam mengikuti pemberian materi yang diberikan.

2. Anak-anak cenderung mulai tertarik untuk mempelajari lebih lanjut mengenai hewan-hewan langka di Indonesia.

3. Kemampuan motorik halus anak-anak yaitu dalam melipat kertas (origami) terlihat menjadi lebih baik dalam beberapa proses tahapan penglipatan kertas.

\section{DAFTAR PUSTAKA}

Andang Ismail. (2006). Education Games. Yogyakarta: PT Pilar Media.

Andayani, Wijil Yuningtias. (2012). Peningkatan Kemampuan Motorik Halus Anak Melalui Melipat Pada Siswa Kelompok A Di TK It Mekar Insani Suryodiningratan Tahun Ajaran 2011/2012. Tersedia pada http://eprints. uny.ac.id /7942/3/.

Arikunto, Suharsimi. (2006). Prosedur Penelitian Suatu Pendekatan Praktik. Jakarta: Rineka Cipta.

Bambang, Sujiono. (2008). Metode Pengembangan Fisik. Jakarta: Universitas Terbuka.

Djoehaeni, Heny. (2016). Implementasi Model Pembelajaran Contextual Teaching Learning Dalam Pembelajaran Pendidikan Lingkungan Hidup Di Taman Kanak Kanak. Edutech, Vol.15, No.1, Februari 2016.

Hurlock, E. B. (2013). Psikologi Perkembangan Suatu Pendekatan Sepanjang Rentang Kehidupan. Jakarta: Gelora Aksara Pratama.

Jumilah. (2014). Meningkatkan Keterampilan Motorik Halus dengan Melipat Kertas Sederhana Melalui Metode Demonstrasi 
Jaya Lestari Desa Beliti Jaya. Journal PG-PAUD. Volume 5. No 3.

Karmachela, Hira. (2008). Origami dan Anak. Surabaya: Insan Cendikia hal 1.

Soemantri, M. S. (2005). Model Pengembangan Ketrampilan Motorik Anak Usia Dini. Jakarta: Departemen Pendidikan Nasional.

Sugiyono. (2007). Metode Penelitian Pendidikan (Pendekatan Kuantitatif, Kualitatif dan $R \& D$ ). Bandung: Alfabeta

Sumantri. (2005). Model Pengembangan Keterampilan Motorik Anak Usia Dini. Jakarta: Departemen Pendidikan Nasional.

William B. Stapp and Dorothy A.Cox. (1979). Environmental Education Activities Manual. Michigan.

https://news.detik.com/berita/3352548/sekolah -sei-pantai-ketika-murid-sd-diajaripelestarian-ekosistem-laut.

https://bali.tribunnews.com/2018/07/26/kampa nyekan-anak-anak-cinta-ekosistem-laut. 